\title{
Comparative determination of phytochemical, proximate and mineral compositions in various parts of Portulaca oleracea L.
}

\author{
Chinelo Anthonia Ezeabara ${ }^{1,}$, , Ikeh, Chigozie Faith ${ }^{1}$, Chinyere Veronica Ilodibia ${ }^{1}$, \\ Bibian Okwuchukwu Aziagba1, Ogochukwu Esther Okanume ${ }^{2}$, Mbaekwe, Ebenezer Ike ${ }^{1}$ \\ ${ }^{1}$ Department of Botany, Nnamdi Azikiwe University, P.M.B. 5025 Awka, Anambra State, Nigeria \\ ${ }^{2}$ Department of Plant Science and Technology, University of Jos, Plateau State, Nigeria
}

Email address:

e.chinelo5@yahoo.com (C.A. Ezeabara)

To cite this article:

Chinelo Anthonia Ezeabara, Ikeh, Chigozie Faith, Chinyere Veronica Ilodibia, Bibian Okwuchukwu Aziagba, Ogochukwu Esther Okanume, Mbaekwe, Ebenezer Ike. Comparative Determination of Phytochemical, Proximate and Mineral Compositions in Various Parts of Portulaca oleracea L.. Journal of Plant Sciences. Vol. 2, No. 6, 2014, pp. 293-298. doi: 10.11648/j.jps.20140206.15

\begin{abstract}
Aqueous and ethanol extracts of leaf, stem and root of Portulaca oleracea L. were analyzed for phytochemical constituents and compared, whereas only aqueous extract was used for proximate and mineral composition determinations. There were presence of alkaloid, flavonoid, phenol, saponin, sterol, tannin and terpenoid in the leaf, stem and root of both extracts. Alkaloid and saponin have highest concentrations in both aqueous and ethanol extracts. High concentrations of calcium, magnesium, phosphorus and potassium were present in the leaf, stem and root, whereas iron content was least in all the parts. Level of crude protein, crude fibre and fat were highest in the leaf while carbohydrate was highest in the stem and least in the leaf at $p>0.05$ level of significance. Generally, it was observed that various parts of Portulaca oleracea contained different concentrations of phytochemicals and nutrients. This work, therefore, confirmed the plant's indigenous uses. In addition, it proposed extraction of the bioactive compounds and nutrients from them for manufacture of food supplements and development of new drugs. Ethanol extract of this plant is preferable for extraction of saponin, tannin and terpenoid whereas both aqueous and ethanol extracts would produce good level of alkaloid, flavonoid, phenol and sterol.
\end{abstract}

Keywords: Portulaca oleracea, Aqueous extract, Ethanol extract, Leaf, Stem, Root, Alkaloid, Saponin, Potassium, Protein

\section{Introduction}

Portulaca oleracea L., a member of family Portulacaceae, is a warm climate, annual, green herb, with branched and succulent stems which are decumbent near the base and ascending near the top to a height of $15-30 \mathrm{~cm}$ [1]. It is commonly known as garden purslane, pigweed, moss rose, pusley, little hogweed, common purslane as well as purpleflowered purslane. Portulaca oleracea has different names in various ethnic groups in Nigeria. It is known as "Ntioke", "Ntilimoke", "Ntiike" or "Idiridi" in Igbo; "Esan omode" or "Papasan" in Yoruba; "Babbajibji" or "Halshen saniya" in Hausa and "Eferemakara" in Efik [2,3]. This implied an extensive distribution of this plant in Nigeria.

Since time immemorial, human populations have always been in search for plant with therapeutic potentials. Although orthodox medicine has been accepted by some populations of the world yet greater percentage still relies on natural remedies because of their cheap and easy availability. Portulaca oleracea has been reported as a global panacea due to its several medicinal uses [4]. In addition, it is used as a vegetable for soups in Nigeria.

In order to determine whether this plant truly possesses these qualities, it is necessary to investigate the phytochemical constituents and nutrient values of its parts. It is also important to investigate the possible contributions of the solvents used in extraction of the phytochemicals; with the view of finding whether different solvents would isolate the same secondary metabolites as well as yield the same concentrations. 


\section{Materials and Methods}

\subsection{Plant Collection and Preparation of Samples}

The leaves, stems and roots of Portulaca oleracea were collected in June, 2014 at flowering stage. The collection was made at Ifite - Awka of Anambra State, Nigeria. Awka town lies between Latitudes $\left(7^{0} 00\right.$ and $\left.7^{0} 10\right) \mathrm{E}$ and Longitudes $\left(6^{0}\right.$ 05 and $\left.6^{0} 15\right) \mathrm{N}$ in the rain forest zone of Nigeria [5].

The voucher specimen was kept in the herbarium of Department of Botany, Nnamdi Azikiwe University, Awka, Anambra State.

The plant parts (leaves, stems and roots) were air dried at room temperature for four weeks and crushed with sterilized mortar and pestle. Hammer mill was used to grind the plant parts into powder and sieved with a muslin cloth. The powdered samples were stored in an air tight container until use.

\subsection{Aqueous Extraction Method}

Each of the powdered sample materials $(100 \mathrm{~g})$ was soaked for 72 hours in $1000 \mathrm{ml}$ of sterilized distilled water with occasional shaking. The extract was then filtered through a Whatman filter paper (No 42) into different conical flasks.

The water was evaporated using a water bath (GFL, Germany) at $100^{\circ} \mathrm{C}$ for 1 hour and then left overnight at laboratory temperature for evaporation of the remaining water.

\subsection{Ethanol Extraction Method}

Each of the powdered plant materials $(100 \mathrm{~g})$ was packed into a soxhlet apparatus and extracted exhaustively with $500 \mathrm{ml}$ of absolute ethanol for 8 hours. The ethanol was evaporated using a water bath (GFL, Germany) at $40^{\circ} \mathrm{C}$ for 2 hours and then left overnight at laboratory temperature for evaporation of the remaining ethanol.

These yielded semi-solid extracts that were then used for the analyses. Both aqueous and ethanol extracts were used to carry out the phytochemical determination whereas only aqueous extract was used for nutritional analysis.

\subsection{Qualitative and Quantitative Phytochemical Determinations}

Method of Beckett and Stenlake [6] was used to determine the glucosides. Standard methods of Harborne [7] and AOAC [8] were used in the quantitative phytochemical determinations.

\subsection{Nutrient Determinations}

Nutrients present were determined with the methods described by Onwuka [9].

\subsection{Statistical Analysis}

SPSS software version 20 was used for the statistical analysis. All data were checked for normality (KolmogorovSmirnov test) and tested for homogeneity (Leven median test). One-Way-Anova (F-Test) was then used to analyze the data at 5\% level of probability. Duncan's multiple range test (DMRT) was used to separate the means and data were presented as mean \pm standard deviation of triplicate determinations.

\section{Results}

The results of phytochemical analysis were shown in Figure 1 and Table 1. Results of proximate and mineral analyses were presented in Tables 2 and 3 respectively.

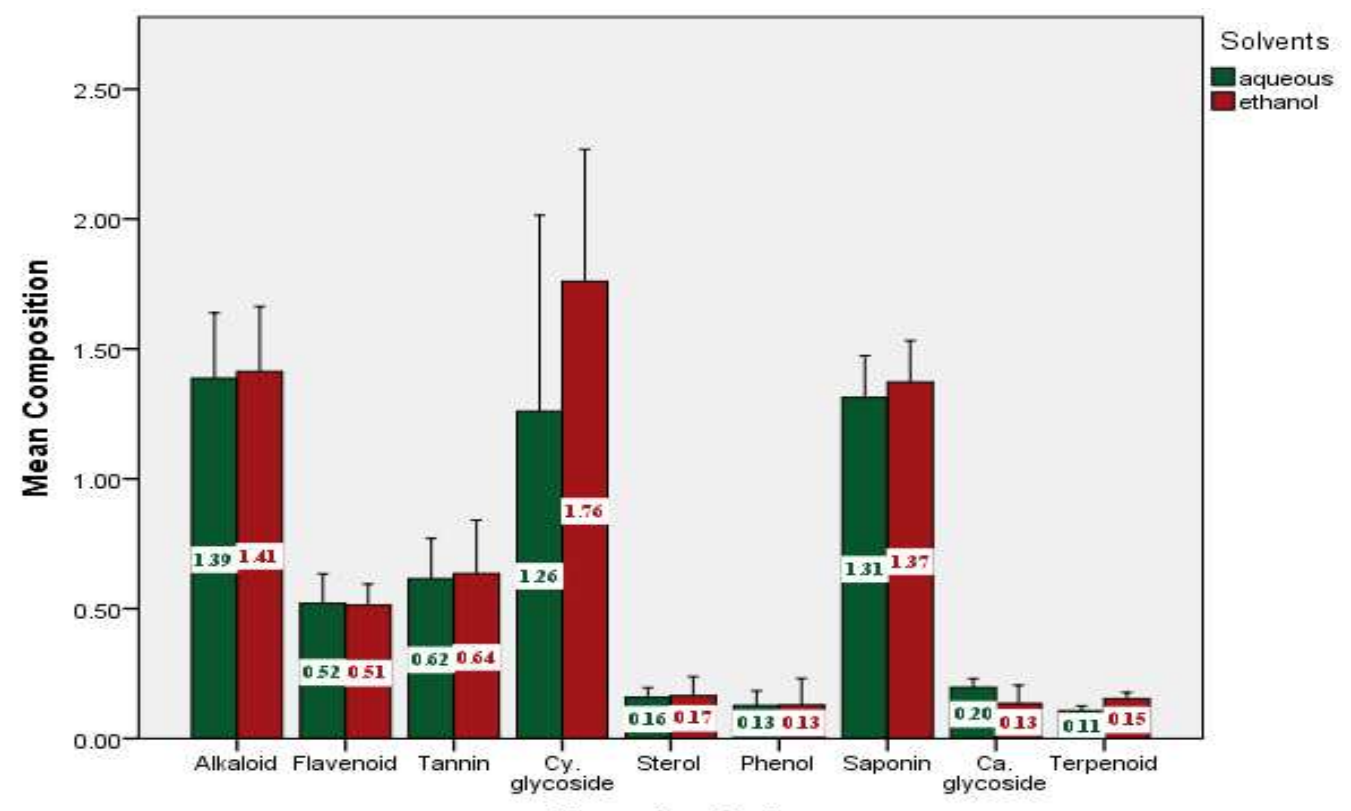

Phytochemicals

Error Bars: $95 \% \mathrm{Cl}$

Figure 1. Comparison of phytochemical composition of aqueous and ethanol extracts of Portulaca oleracea (\%). 
Table 1. Quantitative phytochemical compositions of leaf, stem and root of aqueous and ethanol extracts of Portulaca oleracea (\%)

\begin{tabular}{|c|c|c|c|c|c|c|c|c|}
\hline \multirow{2}{*}{ Compositions } & \multicolumn{3}{|c|}{ Aqueous Extract } & \multicolumn{3}{|c|}{ Ethanol Extract } & \multirow{2}{*}{ Solvent } & \multirow{2}{*}{ Part of plant } \\
\hline & Leaf & Stem & Root & Leaf & Stem & Root & & \\
\hline Alkaloid & $1.61 \pm 0.01^{\mathrm{c}}$ & $1.46 \pm 0.04^{\mathrm{b}}$ & $1.09 \pm 0.00^{\mathrm{a}}$ & $1.67 \pm 0.03^{\mathrm{d}}$ & $1.43 \pm 0.00^{\mathrm{b}}$ & $1.14 \pm 0.02^{\mathrm{a}}$ & Ns & $* *$ \\
\hline Flavonoid & $0.63 \pm 0.00^{\mathrm{e}}$ & $0.54 \pm 0.00^{\mathrm{d}}$ & $0.39 \pm 0.02^{\mathrm{a}}$ & $0.61 \pm 0.02^{\mathrm{e}}$ & $0.50 \pm 0.00^{\mathrm{c}}$ & $0.44 \pm 0.02^{\mathrm{b}}$ & Ns & $* *$ \\
\hline Phenol & $0.14 \pm 0.02^{\mathrm{c}}$ & $0.18 \pm 0.00^{\text {cd }}$ & $0.06 \pm 0.00^{\mathrm{b}}$ & $0.17 \pm 0.03^{\mathrm{cd}}$ & $0.21 \pm 0.03^{\mathrm{d}}$ & $0.01 \pm 0.00^{\mathrm{a}}$ & Ns & $* *$ \\
\hline Saponin & $1.50 \pm 0.03^{\mathrm{c}}$ & $1.27 \pm 0.03^{\mathrm{b}}$ & $1.17 \pm 0.02^{\mathrm{a}}$ & $1.56 \pm 0.06^{\mathrm{c}}$ & $1.32 \pm 0.04^{\mathrm{b}}$ & $1.24 \pm 0.02^{\mathrm{ab}}$ & $* *$ & $* *$ \\
\hline Sterol & $0.19 \pm 0.00^{\mathrm{b}}$ & $0.17 \pm 0.04^{b}$ & $0.12 \pm 0.00^{\mathrm{a}}$ & $0.24 \pm 0.01^{\mathrm{c}}$ & $0.17 \pm 0.00^{\mathrm{b}}$ & $0.09 \pm 0.00^{\mathrm{a}}$ & Ns & $* *$ \\
\hline Tannin & $0.78 \pm 0.00^{\mathrm{e}}$ & $0.62 \pm 0.02^{\mathrm{c}}$ & $0.45 \pm 0.00^{\mathrm{b}}$ & $0.84 \pm 0.02^{\mathrm{f}}$ & $0.67 \pm 0.00^{\mathrm{d}}$ & $0.40 \pm 0.00^{\mathrm{a}}$ & $* *$ & $* *$ \\
\hline Terpenoid & $0.09 \pm 0.00^{\mathrm{a}}$ & $0.13 \pm 0.00^{\mathrm{b}}$ & $0.10 \pm 0.00^{\mathrm{a}}$ & $0.13 \pm 0.03^{\mathrm{b}}$ & $0.17 \pm 0.03^{\mathrm{c}}$ & $0.16 \pm 0.00^{\mathrm{bc}}$ & $* *$ & $* *$ \\
\hline Cardiac glycoside & $0.16+0.00^{b}$ & $0.23 \pm 0.00^{\mathrm{c}}$ & $0.20 \pm 0.00^{\mathrm{c}}$ & $0.10 \pm 0.00^{\mathrm{a}}$ & $0.22 \pm 0.03^{\mathrm{c}}$ & $0.09 \pm 0.00^{\mathrm{a}}$ & $* *$ & $* *$ \\
\hline Cyanogenic glycoside & $1.67 \pm 0.04^{\mathrm{b}}$ & $0.85 \pm 0.00^{\mathrm{a}}$ & - & $1.76 \pm 0.06^{\mathrm{c}}$ & - & - & Ns & $* *$ \\
\hline
\end{tabular}

Data are mean \pm standard deviation of triplicate determinations. Row with the same superscript is not significantly different.

** Significantly difference; Ns: not significantly difference $(p<0.05)$

Alkaloid, tannin, saponin, sterol, flavonoid, terpenoid and cardiac glycoside were present in both aqueous and ethanol extracts of the leaf, stem and root. Concentrations of alkaloid and saponin were the highest phytochemical present in both aqueous and ethanol extracts of the plant parts with greatest levels in the leaves. Percentage phenol composition was highest in the ethanol extract of the stem $(0.21 \pm 0.03)$ and lowest in the root $(0.01 \pm 0.00)$. Saponin level was highest in the ethanol extract of the leaf $(1.56 \pm 0.06 \%)$ and lowest in the aqueous extract of the root $(1.17 \pm 0.01 \%)$. Highest levels of sterol and tannin contents were found in the leaf $(0.24 \pm 0.01$; $0.84 \pm 0.02 \%)$ and least in the root $(0.09 \pm 0.00 ; 0.40 \pm 0.00 \%)$ respectively. Terpenoid content was highest in the ethanol extract of the stem $(0.17 \pm 0.03 \%)$ and lowest in the aqueous extract of the leaf $(0.09 \pm 0.00 \%)$. Value of cardiac glycoside composition was highest in aqueous extract of the stem $(0.23 \pm 0.00 \%)$ and lowest in the ethanol extract of the root $(0.09 \pm 0.00 \%)$. Level of cyanogenic glycoside composition in the leaf of ethanol $(1.76 \pm 0.06 \%)$ and aqueous $(1.67 \pm 0.04 \%)$ extracts were low, whereas it was absent in the root of aqueous extract, stem and root of ethanol extract (Table 1). Possible contribution of the solvents in extraction of alkaloid, cyanogenic glucoside, flavonoid and sterol was not significant at $p>0.05$ whereas for cardiac glucoside, saponin, tannin and terpenoid, it was (Figure 1 and Table 1).

Crude fibre content was highest in the leaf $(15.91 \pm 0.014 \%)$ and least in the stem $(13.34 \pm 0.085 \%)$. The leaf contained the highest level of crude protein $(17.53 \pm 0.106 \%)$ with least in the root $(7.53 \pm 0.106 \%)$; whereas carbohydrate content was highest in the stem $(62.47 \pm 0.573 \%)$ and least in the leaf $(42.41 \pm 0.262 \%)$. Percentage fat contents of the leaf and stem were considerably high (Table 2). Level of magnesium content was highest in the root $(138.51 \pm 0.156 \mathrm{mg} / 100 \mathrm{~g})$ and least in the stem $(89.46 \pm 0.226 \mathrm{mg} / 100 \mathrm{~g})$. Phosphorus was $161.77 \pm 0.042 \mathrm{mg} / 100 \mathrm{~g}$ in the root, $135.77 \pm 0.042 \mathrm{mg} / 100 \mathrm{~g}$ in the stem and $156.87 \pm 0.050 \mathrm{mg} / 100 \mathrm{~g}$ in the leaf. Highest value of potassium was found in the leaf $(274.70 \pm 0.141$ $\mathrm{mg} / 100 \mathrm{~g}$ ) whereas the least was found in the stem $(194.46 \pm 0.226 \mathrm{mg} / 100 \mathrm{~g})$. The iron content was $3.79 \pm 0.014$ $\mathrm{mg} / 100 \mathrm{~g} ; 2.62 \pm 0.113 \mathrm{mg} / 100 \mathrm{~g}$ and $4.87 \pm 0.099 \mathrm{mg} / 100 \mathrm{~g}$ in the leaf, stem and root respectively. Sodium content was highest in the root $(85.66 \pm 0.339 \mathrm{mg} / 100 \mathrm{~g})$ and least in the stem $(51.62 \pm 0.028 \mathrm{mg} / 100 \mathrm{~g})$ (Table 3$)$.

Table 2. Mean proximate compositions of leaf, stem and root of aqueous extract of Portulaca oleracea (\%)

\begin{tabular}{lcccc}
\hline Compositions & Leaf & Stem & Root & p-value \\
\hline Carbohydrate & $42.41 \pm 0.262^{\mathrm{a}}$ & $62.47 \pm 0.573^{\mathrm{c}}$ & $50.75 \pm 0.382^{\mathrm{b}}$ & $* *$ \\
Crude protein & $17.53 \pm 0.106^{\mathrm{c}}$ & $8.76 \pm 0.198^{\mathrm{b}}$ & $7.53 \pm 0.106^{\mathrm{a}}$ & $* *$ \\
Crude fibre & $15.91 \pm 0.014^{\mathrm{c}}$ & $13.34 \pm 0.085^{\mathrm{a}}$ & $14.87 \pm 0.042^{\mathrm{b}}$ & $* *$ \\
Fat & $1.63 \pm 0.014^{\mathrm{c}}$ & $1.24 \pm 0.000^{\mathrm{b}}$ & $0.87 \pm 0.042^{\mathrm{a}}$ & $* *$ \\
Ash & $13.71 \pm 0.042^{\mathrm{b}}$ & $6.78 \pm 0.035^{\mathrm{a}}$ & $16.58 \pm 0.177^{\mathrm{c}}$ & $*$ \\
Moisture & $8.82 \pm 0.113^{\mathrm{b}}$ & $7.42 \pm 0.255^{\mathrm{a}}$ & $9.41 \pm 0.014^{\mathrm{c}}$ & $* *$ \\
Dry Matter & $91.18 \pm 0.113^{\mathrm{b}}$ & $92.58 \pm 0.255^{\mathrm{c}}$ & $90.59 \pm 0.014^{\mathrm{a}}$ & $* *$ \\
\hline
\end{tabular}

Values are mean \pm standard deviation of triplicate determinations. Row with the same superscript is not significantly different.

*** Significant difference $(p<0.05)$ 
Table 3. Mean mineral compositions ( $\mathrm{mg} / \mathrm{l} 00 \mathrm{~g}$ ) of leaf, stem and root of aqueous extract of Portulaca oleracea

\begin{tabular}{lcccc}
\hline Compositions & Leaf & Stem & Root & $p$ value \\
\hline Calcium & $183.63 \pm 0.247^{\mathrm{b}}$ & $129.53 \pm 0.106^{\mathrm{a}}$ & $194.77 \pm 0.042^{\mathrm{c}}$ & $* *$ \\
Iron & $3.79 \pm 0.014^{\mathrm{c}}$ & $2.62 \pm 0.113^{\mathrm{a}}$ & $4.87 \pm 0.099^{\mathrm{b}}$ & $* *$ \\
Magnesium & $124.77 \pm 0.042^{\mathrm{b}}$ & $89.46 \pm 0.226^{\mathrm{a}}$ & $138.51 \pm 0.156^{\mathrm{c}}$ & $* *$ \\
Phosphorus & $156.87 \pm 0.050^{\mathrm{b}}$ & $135.77 \pm 0.042^{\mathrm{a}}$ & $161.77 \pm 0.042^{\mathrm{c}}$ & $* *$ \\
Potassium & $274.70 \pm 0.141^{\mathrm{c}}$ & $194.46 \pm 0.226^{\mathrm{a}}$ & $260.79 \pm 0.014^{\mathrm{b}}$ & $* *$ \\
Sodium & $68.67 \pm 0.050^{\mathrm{b}}$ & $51.62 \pm 0.028^{\mathrm{a}}$ & $85.66 \pm 0.339^{\mathrm{c}}$ & $* *$ \\
\hline
\end{tabular}

Data are mean \pm standard deviation of triplicate determinations. Row with the same superscript is not significantly different.

**Significant difference $(p<0.05)$

\section{Discussion}

The results revealed high concentrations of alkaloid and saponin as well as low level of other phytochemicals in both aqueous and ethanol extracts of all the parts of Portulaca oleracea. This indicated that secondary metabolites accumulate in different parts of plants in varying concentrations.

There was no significant difference between the aqueous and ethanol extracts of parts of this plant on the yield of all the phytochemicals except for those of saponin, tannin, cardiac glucoside and terpenoid. With exception of cardiac glucoside, ethanol extracts yielded higher quantity of others. These indicated that any of the extracts could be used for extraction of alkaloid, flavonoid, phenol and sterol whereas ethanol is preferable for extraction of saponin, tannin and terpenoid. In addition, aqueous extract would isolate higher quantity of cardiac glucoside.

Various traditional uses of Portulaca oleracea in health care delivery have been reported. Purslane is clinically effective for treatment of oral lichen [10] and its leaves are used to treat insect or snake bites on the skin, boils, sores, pain from bee stings, bacillary dysentery, diarrhoea, hemorrhoids, postpartum bleeding and intestinal bleeding [11]. The whole plant is used for treatment of kidney and urinary problems in Nigeria [12].These could be as a result of the bioactive constituents of the plant which have been reported to have a wide range of biological and pharmacological activities. Alkaloid has been reported to have anti-hyperglycemic and anti-inflammatory [13]; anaesthetic and analgesic properties [14,15]. Flavonoid has anti-allergic, anti-inflammatory, anti-oxidative, antimicrobial, anti-diarrhoea and anticancer activities [16]. Saponin has been revealed to possess antinematicidal, molluscicidal, insecticidal and antioxidant [17,18]; anti-cancer [19][20]; aphrodisiac [21,22]; anti-protozoal [23]; antibiotic, antifungal, antiviral, hepatoprotective, anti-inflammatory and anti-ulcer properties $[24,25,26]$.Tannin has been reported to be potentially used as an antiviral, antibacterial and anti-parasitic $[15,27]$ and anti-diarrhoeal agent $[28,29]$. Antibacterial and antineoplastic functions of terpenoids have been reported [30].

Moreover, Portulaca oleracea contained great nutritional value. Levels of protein, fibre, fat, calcium, magnesium, phosphorus and potassium, contained in parts of this plant were relatively high. Portulaca oleracea was reported to be a rich source of omega-3-fatty acids, which is important in preventing heart attacks and strengthening the immune system [31]. Highest concentrations of all the minerals, with exception of potassium were found in the root with the least in the stem. High magnesium intake may play a role in the primary prevention of cerebral infarction [32]. Diets high in potassium are associated with improved blood pressure control [33]; reduction in kidney stone risks [34] and may lower urinary calcium excretion [35]. Calcium is associated with bone health. Portulaca oleracea could be regarded as good sources of these minerals. Besides, absence of cyanogenic glycoside in the root of aqueous extract as well as in the stem and root of ethanol extract; in addition to the low level in the leaf of both aqueous and ethanol extracts, and stem of aqueous extract, indicated that this plant is not poisonous and this encouraged its use as a natural food.

\subsection{Conclusion and Recommendation}

Generally, the phytochemicals and nutrients found in various parts of Portulaca oleracea were in different concentrations. In view of the highest levels of carbohydrate, phenol and terpenoid present in the stem, in addition to the highest values of the minerals detected in the root; stem and root of Portulaca oleracea could be regarded as underutilized parts in health care delivery, thus, the inclusion of these parts as food and drug sources is suggested.

In addition, all parts of Portulaca oleracea were replete with therapeutic agents and thus, it could be regarded as one of the group of plants from which they could be isolated and used in development of drugs. Solvents used in the extraction contributed to the quantity of some phytochemicals present; hence, ethanol extract of this plant is preferable for extraction of saponin, tannin and terpenoid whereas any of aqueous and ethanol extracts would produce good level of alkaloid, flavonoid, phenol and sterol.

Portulaca oleracea is nutritious, nontoxic and therefore, the ethnobotanical use of the leaf and stem as vegetable as well as the whole plant as drug is encouraged. It can be considered as a safe food for diabetic patients as result of its low carbohydrate content; as well as high potassium level 
which has been reported to be associated with improved blood pressure control.

\section{References}

[1] L.W. Mitich, Common Purslane (Portulaca oleracea), Weed Technology, 1997; 11 (2): 394-397.

[2] H.M. Burkill, The Useful Plants of West Tropical Africa, 2nd ed., Vol 1. Royal Botanic Garden, Kew.1985; pp. 960.

[3] M. Iwu, Handbook of African Medicinal Plants, 2nd ed. CRC Press, Boca Raton. 1993; pp. 464.

[4] Y.Y. Lim, E.P.L. Quah, Antioxidant properties of different cultivars of Portulaca oleracea. Food Chemistry, 2007; 103:734-740.

[5] W. Richard, Invasive Species Specialist Group (ISSG), Global Invasive Species Data Base. Annals of Botany, 2005; 21: 287-314.

[6] A.H. Beckett, J.B. Stenlake, Practical Pharmaceutical Chemistry: Part 1. Continuum International Publishing Group Ltd., London. 1988; pp. 235.

[7] J.B. Harborne, Phytochemical Methods: A Guide to Modern Techniques of Plant Analysis, 3rd ed. Chapman and Hall, London. 1988; pp.302.

[8] Association of Official Analytical Chemists, Official Methods of Analysis, 15th ed. International Association of Official Analytical Chemists, Washington D.C. 1990; pp. 409.

[9] G.I. Onwuka, Food Analysis and Instrumentation: Theory and Practice. Naphthali Prints, a Division of HG Support Nigeria Ltd., Lagos. 2005; pp. 250.

[10] F. Agha-Hosseini, K., Borhan-Mojabi, H.R. Monsef-Esfahani, I. Mirzaii-Dizgah, S. Etemad-Moghadam, A. Karagah, Efficacy of purslane in the treatment of oral lichen planus. Phytotherapy Research, 2010; 24 (2): 240-4.

[11] D. Bensky, Chinese Herbal Medicine, Materia Medica. Eastland Press Inc., China. 2004; pp.1050.

[12] J.C. Okafor, Tropical Plants in Health Care Delivery in Nigeria. Ibadan: Bookbuilders, 2013; pp. 188.

[13] G.A. Aderinokun, J.O. Lawoyin, C.O. Onyeaso, Effect of two common Nigerian chewing sticks on gingival health and oral hygiene. Odonto-Stomatologie Tropicale, 1999; 22 (87): 1318.

[14] D. Herourat, R.S. Sangwin, M.A. Finiaux, B.S. SangwanNorrell, Variations in the leaf alkaloid content of androgenic diploid plants of Daturu innoxia Planta medical. Journal of Medicinal Plant Research, 1988; 54: 14-20.

[15] O.V. Njoku, C. Obi, Phytochemical constituents of some selected medicinal plants. African Journal of Pure and Applied Chemistry, 2009; 3 (11):228-233.

[16] Y. Yamamoto, R.B. Gaynor, Therapeutic potential of inhibition of the NF-B pathway in the treatment of inflammation and cancer. Journal of Clinical Investigation, 2001; 107 (2): 135-42.

[17] G. Francis, Z. Kerem, H.P.S. Makkar, K. Becker, The biological action of saponins in animal systems: a review.
British Journal of Nutrition, 2002; 88:587-605.

[18] M.P. Argentieri, T.A. D'Addobbo, A. Agostinelli, M. Jurzysta, P. Avato, Evaluation of nematicidal properties of saponins from Medicago species. European Journal of Plant Pathology, 2007; 120:189-197.

[19] J. Shi, K. Arunasalam, D. Yeung, Y. Kakuda, G. Mittal, Y. Jiang, Saponins from edible legumes: Chemistry, processing and health benefits. Journal of Medical Food, 2004; 7:67-78.

[20] S.G. Sparg, M.E. Light, J. van Staden, Biological activities and distribution of plant saponins. Journal of Ethno Pharmacology, 2004; 94:219-243.

[21] K. Gauthaman, P.G. Adaikan, R.N. Prasad, Aphrodisiac properties of Tribulus terrestris extract (Protodioscin) in normal and castrated rats. Life Science, 2002; 71:1385-96.

[22] Guardian, Herbal cocktail better than Viagra in humans, say researchers, April 19, 2009; Lagos, Nigeria.

[23] H.P.S. Makkar, T. Norvsambuu, S. Lkhagvatseren, K. Becker, Plant Secondary Metabolites in some Medicinal Plants of Mongolia Used for Enhancing Animal Health and Production. Tropicultura, 2009; 27(3):159-167.

[24] K.R. Price, G.R. Fenwick, The Chemistry and Biological significance of saponins in foods and feeding stuffs. International Review in Food Science and Nutrition, 1990; 157:62.27.

[25] M.J. Just, M.G. Recsio, R.M. Gner, M.J. Cuellar, S. Marez, A.R., Bilia, J. Rios, Anti-inflammatory activity of unusual lupane saponins from Buleurum fruiticescens. Planta Medica, $1998 ; 64(5): 404-407$.

[26] C.A. Ezeabara, C.U. Okeke, B.O. Aziagba, C.V. Ilodibia, A.N. Emeka, Determination of saponin content of various parts of six Citrus species. International Research Journal of Pure and Applied Chemistry, 2014; 4(1):137-143

[27] L. Lu, S.W. Liu, S.B. Jiang, S.G. Wu, Tannin inhibits HIV-1 entry by targeting gp 41. Acta Pharmacology Sinica, 2004; 25 (2): 213-218.

[28] F. Tian, B. Li, B. Ji, Antioxidant and antimicrobial activities of consecutive extracts from Galla chinensis: the polarity affects the bioactivities. Food Chemistry, 2009; 113 (1):173-179.

[29] H. Kolodziej, A.F. Kiderlen, Anti-leshmanial activity and immune modulatory effects of tannin and related compounds on leshmania parasitized RAW 264.7 cells. Phytochemistry, 2005; 66 (17): 2056- 71.

[30] S. Foster, J.A. Duke, A Field Guild to Medicinal Plants and Herbs, 2nd ed. Houghton Mifflin Company, Boston. 2000; pp. 1657.

[31] A.P. Simopoulos, H.A. Norman, J.E. Gillaspy, J.A. Duke, Common purslane: a source of omega-3 fatty acids and antioxidants. Journal of the American College of Nutrition, 1992; 11(4):374-82.

[32] S.C. Larsson, M.J. Virtanen, M. Mars, S. Männistö, P. Pietinen, D. Albanes, J. Virtamo, Magnesium, calcium, potassium, and sodium intakes and risk of stroke in male smokers. Archives of Internal Medicine, 2008; 168 (5): 459-65.

[33] A.A. McDonough, M.T.X. Nguyen, How does potassium supplementation lower blood pressure? Renal Physiology, 2012; 302:F1124-5. 
[34] E.N. Taylor, T.T. Fung, G.C. Curhan, DASH-style diet associates with reduced risk for kidney stones. Journal of the American Society of Nephrology, 2009; 20:2253-2259.

[35] P.K. Whelton, J. He, J.A. Cutler, F.L. Brancati, L.J. Appel, D.
Follmann, M.J. Klag, Effects of oral potassium on blood pressure: meta-analysis of randomised controlled clinical trials. The Journal of the American Medical Association, 1997; 277:1624-32. 